\title{
Temporal-spatial evolution of the lagged effect of Karst drainage basin for rainfall-runoff in Central Guizhou of China
}

\author{
Zhonghua $\mathrm{He}^{1}$, Cuiwei Zhao ${ }^{1}$, Qi Zhou ${ }^{2}$, Hong Liang ${ }^{1}$, and zhaohui Yang ${ }^{3}$ \\ ${ }^{1}$ Guizhou Normal University \\ ${ }^{2}$ Guizhou University \\ ${ }^{3}$ Emergency Management
}

June 23, 2020

\begin{abstract}
The occurrences of atmospheric precipitation and runoff do not coincide with each other, but rather demonstrate a certain lag in time. Meanwhile the lagged time and intensity are affected by the water storage capacities, which is related to the occurrence of droughts. This paper will develop the lagging index (LI) based on the measured data of 56 rainfall stations and 11 hydrological stations in the Central Guizhou of China, and analyze the spatio-temporal evolution characteristics of rainfall-runoff. The studies show that (1) the lagged effect of runoff to rainfall in the Central Guizhou of China mainly shows the 3 lagged periods with the lagged distribution areas accounting for more than $80 \%$ of the total areas. (2) The order of spatio-temporal distribution differences of the lagged intensities is the lagged period $2(\mathrm{Cv}=0.62)$
\end{abstract}

\section{Hosted file}

Temporal--spatial evolution of the lagged effect_2020.6.20.doc available at https: //authorea.com/users/299863/articles/461912-temporal-spatial-evolution-of-the-laggedeffect-of-karst-drainage-basin-for-rainfall-runoff-in-central-guizhou-of-china

\section{Hosted file}

Fig.1-4.doc available at https://authorea.com/users/299863/articles/461912-temporal-spatialevolution-of-the-lagged-effect-of-karst-drainage-basin-for-rainfall-runoff-in-centralguizhou-of-china

\section{Hosted file}

Tab.1-8.doc available at https://authorea.com/users/299863/articles/461912-temporal-spatialevolution-of-the-lagged-effect-of-karst-drainage-basin-for-rainfall-runoff-in-centralguizhou-of-china 